\title{
The effect of thyroid hormone deficiency on erythropoiesis in dogs
}

\author{
Olga Aniołek \\ Lazarski University, Warsaw, Poland \\ Received July 20, 2018 \\ Accepted June 13, 2019
}

\begin{abstract}
This research aimed to evaluate the effect of thyroid hormone deficiency on the erythrocytic system in dogs. Dogs with clinical symptoms of hypothyreosis such as obesity, hyperpigmentation, and lethargy were selected. The dogs demonstrating breed predisposition to hypothyreosis were incorporated in the analysis: Dachshunds, Retrievers, and mixed-breed dogs. A detailed history was taken and clinical, hormonal, biochemical and haematological blood tests were performed. Peripheral blood samples were taken from 53 dogs. Finally, the dogs with the initial T4 (thyroxine) concentration $<1.3 \mu \mathrm{g} / \mathrm{dl}$ and animals demonstrating clinical improvement after a 2-month therapy with levothyroxine at a dose of $10 \mu \mathrm{g} / \mathrm{kg}$ administered per os two times a day were qualified. The animals between 10 months to 13 years of age were divided into two groups: clinically healthy (control group, $\mathrm{n}=35$ ) and dogs presenting clinical symptoms of hypothyreosis (experimental group, $\mathrm{n}=18$ ). In this research, the broadly described normocytic normochromic non-regenerative anaemia was not diagnosed in dogs with hypothyreosis. However, a positive correlation between T4 and red blood cell indices such as the average mass of haemoglobin per red blood cell, concentration of haemoglobin in a given volume of packed red blood cells as well as a negative correlation with haematocrit value was discovered in the experimental group after the 2-month therapy with levothyroxine. These results point to the influence of thyroid hormones on erythropoiesis. This observation is partially consistent with other studies, which noted the casual link between the changes in red blood cell system and the function of thyroid in dogs and humans.
\end{abstract}

Anaemia, thyroxine, haematopoiesis

Anaemia is a common condition accompanying thyroid disorders in humans and animals (Szczepanek-Parulska et al. 2017). Due to their frequent occurrence both the anaemia and thyroid dysfunctions are considered as serious disorders (Rijnberg and Kooista 2010; Vitale et al. 2010; den Elzen et al. 2015; Refaat 2015; Ziglioli et al. 2017). The causal link still remains unclear. It is known that the thyroid hormones have a stimulating effect on erythropoiesis and that they stimulate the production of erythropoietin in iron deficiency anaemia. Therefore, various forms of anaemia may manifest themselves in the course of thyroid dysfunctions. Normocytic normochromic anaemia in the course of hypothyreosis in dogs is the most frequently described type of anaemia in the literature. It may result from bone marrow suppression and deficiencies in erythropoietin, iron, vitamin B12 and folic acid. Additionally, it has been noted that hypoxia resulting from the anaemia disturbs the peripheral conversion of T4 to T3 triiodothyronine) (Omar et al. 2010; Taylor and Rampton 2015). Iron deficiency anaemia and hypothyreosis are considered the causes of mental and behavioural deficiency in humans and animals (Wilson and Curry 2005; Gianoukakis et al. 2009). The thyroid hormones play a key role in haematopoiesis, especially in erythropoiesis. They have a direct stimulating effect on the proliferation of erythrocyte precursors, but they also stimulate the erythropoiesis by increasing the erythropoietin gene expression and erythropoietin production in kidneys (Malgor et al. 1975; Golde et al. 1977; Fandrey et al. 1994; Dorgalaleh et al. 2013).

Address for correspondence: 
Experimental research has shown an increased erythroid colony growth induced by fT3 (free triiodothyronine) (Malgor et al. 1995). In reality, in patients with hypothyreosis, the number and proliferation of erythroid cells in bone marrow decreases (Das et al. 1975). In turn, iron deficiency anaemia may have a negative effect on the influence of the state of the thyroid hormone (Khatiwada et al. 2016). Iron is essential for the functioning of thyroid peroxidase (TPO), which plays an important role in thyroid hormone synthesis. The evaluation of the influence of thyroid hormone deficiency on the haematopoietic system in dogs was the subject of this study.

\section{Materials and Methods}

\section{Animals}

The research was carried out on dogs of Polish origin. The study was conducted in accordance with EU-Convention of the protection of animals used for scientific purpose (Revised Directive 86/609/the EEC - Directive of the European Parliament and of the Council on the protection of animals used for scientific purpose.

We analysed the patients of the Small Animal Clinic of the Faculty of Veterinary Medicine at the Warsaw University of Life Sciences in Poland. Animals qualified for the research had not been treated or vaccinated over the period of two months prior to the tests. Breeds prone to canine hypothyroidism were selected for the test: Dachshunds, Retrievers, and cross-breeds. The animals were not castrated or sterilized. Animal histories were taken and the subjects had to undergo clinical, hormonal, biochemical tests and morphology in all dogs. Blood was collected from a vein. In the end, animals with an initial level of T4 $<1.3 \mu \mathrm{g} / \mathrm{dl}$ and those which had shown clinical improvement after a 2-month treatment with levothyroxine $10 \mu \mathrm{g} / \mathrm{kg}$ (Forthyron, Pfizer, Warsaw, Poland) given daily in two doses per os were qualified for the research. All dogs responded to therapy. Healthy dogs were used as the control group. Their condition was estimated on the basis of medical history and clinical examination. Results of morphological examination of blood and the biochemical profile were used in order to rule out diseases affecting the respective systems. Pregnant females were removed from the tests. Dogs with hypothyroidism have one or more of these symptoms: weight gain without an increase in appetite, lethargy and lack of desire to exercise, cold intolerance, slow heart rate, increased dark pigmentation in the skin, very thin to nearly bald hair coat (Campora et al. 2011). Dogs with the classification to the experimental group showed clinical symptoms of hypothyroidism, did not respond in the TRH stimulation test, in thyroid gland biopsy they had lymphocytic thyroiditis. Two groups of animals aged between 10 months to 13 years of age were created: clinically healthy (control group, $\mathrm{n}=18$ ) and a group showing clinical symptoms of hypothyroidism (experimental group, $\mathrm{n}=35$ ). The group of clinically healthy dogs had the same blood tests. The experimental group consisted of: Dachshunds $(n=4)$, Golden Retrievers $(n=6)$, and cross-breeds $(n=8)$. The control group consisted of Dachshunds $(n=3)$, Golden Retrievers $(n=6)$, and cross-breeds $(n=26)$. The iron and vitamin B12 concentrations and folic acid levels were not analysed.

\section{Haematological examinations}

Haematological examinations were carried out within $20 \mathrm{~min}$ from the moment the blood sample was taken. The tests determined the values of: haemoglobin $(\mathrm{Hg})$, haematocrit $(\mathrm{Ht})$, total red cell count $(\mathrm{RBC})$, total white cell count (WBC), mean cell volume (MCV), mean corpuscular haemoglobin (MCH), mean corpuscular haemoglobin concentration (MCHC), platelet count (PLT) and included qualitative evaluation of the differential leukocyte count and differential blood count. Determination of $\mathrm{Ht}, \mathrm{RBC}, \mathrm{WBC}, \mathrm{MCV}, \mathrm{MCH}$ and $\mathrm{MCHC}$ was performed using impedance methods (Abacus, Diatron, France). Haemoglobin concentration was measured using the colorimetric method at a wavelength of $540 \mathrm{~nm}$. The mentioned parameters were determined using a haematology analyser (Abacus). The differential leukocyte count was evaluated manually at a $\times 1000$ magnification using the Olympus CX 40 microscope (France) according to Schilling on the basis of blood smears stained using the Pappenheim method with May-Grünwald-Giemsa (MGG) reagents (Campora et al. 2011).

\section{Marking of T4, TSH levels}

Levels of the thyrotropic hormone (TSH) were marked using chemiluminescent, two-point solid phase immunometric test (Immulite canine TSH, Diagnostic Products Corporation, DPC, Los Angeles, CA). Coefficients within one variability amounted to 5,4 and $3.8 \%$ for TSH levels of $0.2,0.5$ and $2.6 \mu \mathrm{g} / 1$, respectively. Mid-test deviation reached 6.3 and $8.2 \%$ for TSH of 0.16 and $2.8 \mu \mathrm{g} / 1$, respectively. The TSH levels measured in Immulite canine TSH test after a serial dilution of samples taken from three dogs showed correct linearity in the whole spectrum of calibration. Cross-reactivity with the follicle stimulating hormone (FSH) and luteinizing hormone $(\mathrm{LH})$ was infinitesimal. The test unit contained a sphere coated with mice monoclonal antibody anti-c-TSH. The reagent strip contained $6.5 \mathrm{ml}$ alkaline phosphatase isolated from calf intestine coupled with rabbit anti-c-TSH polyclonal antibody with buffer in preservative. Total concentration of T4 using species-specific anti-T4 monoclonal antibodies (mouse monoclonal antibody anti canine T4) was marked using chemiluminescent, 
two-point solid phase immunometric test (Immulite canine Total T4, Diagnostic Products Corporation, DPC, Los Angeles, CA). Mid-test deviation reached $13.8 \%$ and $8.2 \%$ for tyroxine at $0.624 \mu \mathrm{g} / \mathrm{dl}$ and $1.95 \mu \mathrm{g} / \mathrm{dl}$, respectively.

Statistical analysis

The obtained data were analysed using the SPSS 14.0 software. The results were presented as an arithmetic mean with standard error (SE). The analysed parameters were not characterised by normal distribution. Normality of distribution was checked using Kolmogorov-Smirnov test. In order to determine the significance of the difference between two independent properties, Mann-Whitney U test was used. Significance between several independent properties was determined using Kruskal-Wallis test. Dependency between the analysed parameters was depicted using the Spearman's correlation coefficient. Differences of $P \leq 0.05$ were considered significant, whereas those of $P \leq 0.01$ were considered highly significant.

\section{Results}

A significant difference between the breeds for RBC $(P=0.023)$, Ht $(P=0.031$, PLT $(P=0.037)$, and a highly significant difference in the $\mathrm{Hg}$ concentration in the animal group with hypothyreosis was observed in the study (Table 1). Changes in the haematological picture within different breeds were documented. A significant difference in the mean corpuscular volume of blood cell $\mathrm{MCV}(P=0.028)$ was noted between dogs with hypothyreosis and clinically healthy dogs with the mean value of $65.03 \mathrm{fl}$ for clinically healthy animals and $67.28 \mathrm{fl}$ for the experimental group. Results of blood smear evaluation are shown in Table 2. A positive correlation between T4 and red blood cell indices, such as $\mathrm{MCH}, \mathrm{MCHC}$ and negative correlation with haematocrit was observed (Table 3). In this study using anti-dog c-TSH mouse monoclonal antibodies, the values fell for all the patients within the range of 0 to the referential value $(0.60 \mathrm{ng} / \mathrm{ml})$, like for the dogs with euthyroidism. The hormone levels were unmeasurable using anti-human TSH mouse monoclonal antibodies, which underlines the validity of use of monoclonal antibodies directed against species-specific thyreotropin with chemiluminescence as the indicator reaction. Anti-TSH mouse monoclonal antibodies did not cross-react with cTSH. The hormone values are unmeasurable using anti-TSH mouse monoclonal antibodies.

Correlations between cT4, T4 and c-TSH are shown in Table 4. The levels of cTSH, cT4 and T4 in blood serum of control and experimental groups by dog breeds are shown in Tables 5 and 6.

\section{Discussion}

Changes in the haematological picture within different breeds were documented. Separate referential values were created for Greyhounds which have higher Ht MCV and HGB concentrations as well as lower levels of WBC and PLT compared to other breeds (Porter and Canaday 1971; Sullivan et al. 1994; Guyton and Hall 2006; Campora et al. 2011; Zaldivar-Lopez et al. 2011). Higher PCV, HCT, RBC and HGB concentrations were noted for Dachshunds compared to mixed breed dogs (Torres et al. 2014). The reasons why the difference between breeds in the aforementioned parameters was observed only in the group of animals with hypothyreosis remains unclear. Lower MCV is observed in conditions of iron deficiency, whereas elevated MCV is a sign of folic acid and vitamin B12 deficiency. In a studz by Dorgalaleh et al. (2013) both the hyperthyreosis and the hypothyreosis were connected to a significantly lower mean corpuscular volume of blood cells $(\mathrm{MCV})$, mean mass of haemoglobin of a blood cell $(\mathrm{MCH})$, mean $\mathrm{Hb}$ concentration in a blood cell (MCHC), HB and HCT but also higher red blood cell distribution width (RDW) compared to the control group (Dorgalaleh et al. 2013). This research had its limits, as the iron and vitamin B12 concentrations and folic acid levels were not analysed. According to the literature data, the mean value of $\mathrm{MCV}$ in dogs with high potassium concentration were significantly higher when compared to dogs with low potassium concentration but 
Table 1. Results of haematological examinations of dogs from control and experimental groups with regard to breed.

\begin{tabular}{|c|c|c|c|c|c|c|c|c|}
\hline \multirow{2}{*}{$\begin{array}{l}\text { Haematological } \\
\text { index }\end{array}$} & \multirow[t]{2}{*}{ Breed } & \multirow{2}{*}{$\begin{array}{l}P \text { between } \\
\text { groups }\end{array}$} & \multicolumn{3}{|c|}{ Control group } & \multicolumn{3}{|c|}{ Experimental group } \\
\hline & & & $\mathrm{N}$ & Mean & SE & $\mathrm{N}$ & Mean & SE \\
\hline WBC & Dachshund & 0.057 & 3 & 10.80 & 0.26 & 4 & 8.57 & 0.64 \\
\hline \multirow[t]{3}{*}{$\left(10^{9} / \mathrm{I}\right)$} & Retriever & 0.485 & 6 & 11.51 & 0.97 & 6 & 10.66 & 1.53 \\
\hline & Other & 0.347 & 26 & 10.80 & 0.67 & 8 & 12.46 & 1.47 \\
\hline & Total & 0.639 & 35 & 10.92 & 0.52 & 18 & 10.99 & 0.88 \\
\hline \multicolumn{4}{|c|}{$P$ between breeds within respective groups } & \multicolumn{2}{|l|}{0.830} & \multicolumn{3}{|c|}{$0.023 *$} \\
\hline $\mathrm{RBC}$ & Dachshund & 0.857 & 3 & 7.80 & 0.26 & 4 & $7.99^{\mathrm{A}}$ & 0.33 \\
\hline \multirow[t]{3}{*}{$(10$ 12/I) } & Retriever & 0.485 & 6 & 7.08 & 0.41 & 6 & $6.69^{\mathrm{B}}$ & 0.14 \\
\hline & Other & 0.092 & 26 & 7.57 & 0.17 & 8 & $6.98^{\mathrm{B}}$ & 0.25 \\
\hline & Total & 0.067 & 35 & 7.50 & 0.15 & 18 & 7.11 & 0.18 \\
\hline \multicolumn{4}{|c|}{$P$ between breeds within respective groups } & \multicolumn{2}{|l|}{0.552} & \multicolumn{3}{|c|}{$0.026 *$} \\
\hline $\mathrm{Hg}$ & Dachshund & 0.229 & 3 & 17.47 & 0.42 & 4 & $18.68^{\mathrm{A}}$ & 0.71 \\
\hline \multirow{3}{*}{$(\mathrm{mmol} / \mathrm{l})$} & Retriever & 0.589 & 6 & 16.30 & 0.73 & 6 & $15.93^{\text {B }}$ & 0.43 \\
\hline & Other & 0.952 & 26 & 16.53 & 0.35 & 8 & $16.71^{\mathrm{B}}$ & 0.26 \\
\hline & Total & 0.800 & 35 & 16.57 & 0.29 & 18 & 16.89 & 0.33 \\
\hline \multicolumn{4}{|c|}{$P$ between breeds within respective groups } & \multicolumn{2}{|l|}{0.611} & \multicolumn{3}{|c|}{$0.005 * *$} \\
\hline $\mathrm{Ht}$ & Dachshund & 0.400 & 3 & 51.07 & 2.68 & 4 & $54.83^{\mathrm{A}}$ & 1.77 \\
\hline \multirow[t]{3}{*}{$(\%)$} & Retriever & 0.699 & 6 & 47.92 & 2.77 & 6 & $46.03^{\text {B }}$ & 0.96 \\
\hline & Other & 0.618 & 26 & 48.58 & 1.10 & 8 & $50.20^{\mathrm{AB}}$ & 1.75 \\
\hline & Total & 0.511 & 35 & 48.68 & 0.95 & 18 & 49.84 & 1.18 \\
\hline \multicolumn{4}{|c|}{$P$ between breeds within respective groups } & \multicolumn{2}{|l|}{0.711} & \multicolumn{3}{|c|}{$0.031 *$} \\
\hline$\overline{\mathrm{MCV}}$ & Dachshund & 1.000 & 3 & $65.67^{\mathrm{AB}}$ & 1.33 & 4 & 66.75 & 1.11 \\
\hline \multirow[t]{3}{*}{ (fl) } & Retriever & 0.818 & 6 & $67.67^{\mathrm{A}}$ & 0.99 & 6 & 68.83 & 1.78 \\
\hline & Other & 0.110 & 26 & $64.35^{\text {В }}$ & 0.43 & 8 & 66.38 & 1.28 \\
\hline & Total & $0.026 *$ & 35 & 65.03 & 0.42 & 18 & 67.28 & 0.85 \\
\hline \multicolumn{4}{|c|}{$P$ between breeds within respective groups } & \multicolumn{2}{|l|}{$0.028 *$} & & 0.669 & \\
\hline $\mathrm{MCH}$ & Dachshund & 0.629 & 3 & $3.67^{\mathrm{AB}}$ & 0.04 & 4 & 3.73 & 0.11 \\
\hline (fmol) & Retriever & 0.589 & 6 & $3.79^{\mathrm{A}}$ & 0.09 & 6 & 3.90 & 0.09 \\
\hline & Other & 0.120 & 26 & $3.58^{\mathrm{B}}$ & 0.02 & 8 & 3.74 & 0.08 \\
\hline & Total & $0.011 *$ & 35 & 3.62 & 0.03 & 18 & 3.79 & 0.05 \\
\hline$P$ between breeds & jithin respect & rroups & & $0.041 *$ & & & 0.500 & \\
\hline $\mathrm{MCHC}$ & Dachshund & 0.857 & 3 & 21.44 & 0.72 & 4 & 21.33 & 0.77 \\
\hline$(\mathrm{mmol} / \mathrm{l})$ & Retriever & 0.699 & 6 & 21.34 & 0.44 & 6 & 21.61 & 0.30 \\
\hline & Other & 0.253 & 26 & 21.28 & 0.09 & 8 & 21.60 & 0.24 \\
\hline & Total & 0.252 & 35 & 21.31 & 0.11 & 18 & 21.55 & 0.21 \\
\hline$P$ between breeds & jithin respect & rroups & & 0.893 & & & 0.865 & \\
\hline PLT & Dachshund & 0.629 & 3 & 216.33 & 70.13 & 4 & 340.75 & 78.67 \\
\hline$(109 / \mathrm{I})$ & Retriever & 0.394 & 6 & 301.83 & 45.09 & 6 & 253.83 & 24.75 \\
\hline & Other & 0.347 & 26 & 267.38 & 18.37 & 8 & 247.13 & 47.62 \\
\hline & Total & 0.673 & 35 & 268.91 & 16.52 & 18 & 270.17 & 28.32 \\
\hline$P$ between breeds & jithin respect & groups & & 0.662 & & & $0.037 *$ & \\
\hline
\end{tabular}

* Significant difference $(P \leq 0.05)$ between the control and experimental groups within the same breed

**Highly significant difference $(P \leq 0.01)$ between the control and experimental groups within the same breed $\mathrm{A}, \mathrm{B}$ - differences in the mean within groups having no significance were marked using the same superscripts

WBC - total white blood cell count, RBC - total red blood cell count, $\mathrm{Hg}$ - haemoglobin, Ht - haematocrit, MCV - mean corpuscular volume of a blood cell, $\mathrm{MCH}$ - average mass of haemoglobin per red blood cell, $\mathrm{MCHC}$ concentration of haemoglobin in a given volume of packed red blood cells, PLT - total platelet count, N - number of animals, SE - standard error 
Table 2. Results of blood smear evaluation from control and experimental groups with regard to breed.

\begin{tabular}{|c|c|c|c|c|c|c|c|c|}
\hline \multirow{2}{*}{$\begin{array}{l}\text { Haematological } \\
\text { index }\end{array}$} & \multirow[t]{2}{*}{ Breed } & \multirow{2}{*}{$\begin{array}{l}P \text { between } \\
\text { groups }\end{array}$} & \multicolumn{3}{|c|}{ Control group } & \multicolumn{3}{|c|}{ Experimental group } \\
\hline & & & $\mathrm{N}$ & Mean & SE & $\mathrm{N}$ & Mean & SE \\
\hline \multirow{4}{*}{$\begin{array}{l}\text { Band cells } \\
(\%)\end{array}$} & Dachshund & 0.857 & 3 & 2.33 & 1.33 & 4 & 3.00 & 1.15 \\
\hline & Retriever & 0.589 & 6 & 1.67 & 0.80 & 6 & 2.00 & 0.63 \\
\hline & Other & 0.162 & 25 & 4.08 & 0.59 & 8 & 2.38 & 0.53 \\
\hline & Total & 0.236 & 34 & 3.50 & 0.49 & 18 & 2.39 & 0.39 \\
\hline \multicolumn{4}{|c|}{$P$ between breeds within respective groups } & 0.110 & & & 0.620 & \\
\hline \multirow{4}{*}{$\begin{array}{l}\text { Segmented } \\
\text { neutrophils (\%) }\end{array}$} & Dachshund & 0.114 & 3 & $58.00^{\mathrm{AB}}$ & 6.51 & 4 & 72.00 & 1.47 \\
\hline & Retriever & 1.000 & 6 & $62.17^{\text {B }}$ & 3.30 & 6 & 63.33 & 3.40 \\
\hline & Other & 0.510 & 26 & $69.35^{\mathrm{A}}$ & 1.92 & 8 & 72.88 & 2.16 \\
\hline & Total & 0.529 & 35 & 67.14 & 1.71 & 18 & 69.50 & 1.79 \\
\hline \multicolumn{4}{|c|}{$P$ between breeds within respective groups } & \multicolumn{2}{|c|}{$0.046^{*}$} & \multicolumn{3}{|c|}{0.064} \\
\hline Eosinophils & Dachshund & 0.800 & 2 & 4.00 & 3.00 & 3 & $2.00^{\mathrm{A}}$ & 0.58 \\
\hline \multirow[t]{3}{*}{$(\%)$} & Retriever & 0.240 & 6 & 8.83 & 3.17 & 6 & $3.67^{\mathrm{A}}$ & 0.56 \\
\hline & Other & $0.018 *$ & 25 & 4.08 & 0.74 & 7 & $6.71^{\mathrm{B}}$ & 0.94 \\
\hline & Total & 0.426 & 33 & 4.94 & 0.85 & 16 & 4.69 & 0.66 \\
\hline \multicolumn{4}{|c|}{$P$ between breeds within respective groups } & 0.219 & & \multicolumn{3}{|c|}{$0.008 * *$} \\
\hline Lymphocytes & Dachshund & 0.057 & 3 & $37.00^{\mathrm{A}}$ & 4.51 & 4 & $23.50^{\mathrm{AB}}$ & 1.19 \\
\hline \multirow[t]{3}{*}{$(\%)$} & Retriever & 0.394 & 6 & $27.33^{\mathrm{AB}}$ & 3.54 & 6 & $31.00^{\mathrm{A}}$ & 3.58 \\
\hline & Other & 0.164 & 26 & $22.81^{\mathrm{B}}$ & 1.39 & 8 & $18.88^{\text {в }}$ & 2.12 \\
\hline & Total & 0.707 & 35 & 24.80 & 1.40 & 18 & 23.94 & 1.94 \\
\hline \multicolumn{4}{|c|}{$P$ between breeds within respective groups } & 0.019 & & \multicolumn{3}{|c|}{$0.044 *$} \\
\hline
\end{tabular}

*Significant difference $(P \leq 0.05)$ between the control and experimental groups within the same breed

**Highly significant difference $(P \leq 0.01)$ between the control and experimental groups within the same breed

$\mathrm{A}, \mathrm{B}$ - differences in mean within groups having no significance were marked using the same superscripts, $\mathrm{N}$ - number of animals, $\mathrm{SE}$ - standard error

Table 3. Evaluation of correlations between T4, TSH and the haematological changes in blood.

\begin{tabular}{lccccc}
\hline & \multicolumn{2}{c}{ Experimental group } & \multicolumn{2}{c}{ Control group } \\
Parameter & & T4 & TSH & T4 & TSH \\
\hline $\mathrm{Ht}$ & $\mathrm{R}$ & $-0.524^{*}$ & -0.298 & 0.211 & 0.142 \\
& $P$ & 0.026 & 0.23 & 0.224 & 0.415 \\
& $\mathrm{~N}$ & 18 & 18 & 35 & 35 \\
$\mathrm{MCH}$ & $\mathrm{R}$ & $0.484^{*}$ & -0.109 & 0.009 & -0.11 \\
& $P$ & 0.042 & 0.666 & 0.957 & 0.53 \\
& $\mathrm{~N}$ & 18 & 18 & 35 & 35 \\
$\mathrm{MCHC}$ & $\mathrm{R}$ & $0.549^{*}$ & 0.067 & -0.033 & -0.118 \\
& $P$ & 0.018 & 0.793 & 0.851 & 0.5 \\
& $\mathrm{~N}$ & 18 & 18 & 35 & 35 \\
\hline
\end{tabular}

*Significant difference $(P \leq 0.05)$ between the control and experimental groups within the same breed

**Highly significant difference $(P \leq 0.01)$ between the control and experimental groups within the same breed

$\mathrm{R}$ - correlation coefficient, $\mathrm{N}$ - number of animals, $\mathrm{Ht}$ - haematocrit, $\mathrm{MCV}$ - mean corpuscular volume of a blood cell, $\mathrm{MCH}$ - average mass of haemoglobin per red blood cell, T4 - thyroxine, TSH - thyrotropic hormone remained within the normal range (Kaneko et al. 2008). Research in dogs with a phenotype characterised by high potassium concentration has shown that HGB, PCV, $\mathrm{RBC}$ and $\mathrm{MCHC}$ values may be lower in those animals. This suggests that an increase in intercellular waters may cause lower $\mathrm{MCHC}$ and higher MCV in those dogs when considering the normal range for the rest of the variables (Maede et al. 1983). It can also lead to osmotic changes within the blood cells. This research did not cover the electrolyte levels, therefore, it was not possible to check whether osmotic disturbances within 
Table 4. Correlations between cT4, T4, c-TSH in blood serum in the control group and in the experimental group of dogs suffering from hypothyroidism.

\begin{tabular}{|c|c|c|c|c|c|c|c|}
\hline \multirow[b]{2}{*}{ Parameter } & & \multicolumn{3}{|c|}{ Experimental group } & \multicolumn{3}{|c|}{ Control group } \\
\hline & & cT4 & cTSH & $\mathrm{T} 4$ & cT4 & $\mathrm{cTSH}$ & $\mathrm{T} 4$ \\
\hline \multirow[t]{3}{*}{ cT4 } & $\mathrm{R}$ & & 0.168 & $0.610^{* *}$ & & -0.101 & $0.776 * *$ \\
\hline & $P$ & & 0.263 & 0.000 & & 0.423 & 0.000 \\
\hline & $\mathrm{N}$ & & 18 & 18 & & 35 & 35 \\
\hline \multirow[t]{3}{*}{ cTSH } & $\mathrm{R}$ & & 0.089 & -0.207 & & & \\
\hline & $P$ & & 0.558 & 0.097 & & & \\
\hline & $\mathrm{N}$ & & 18 & 35 & & & \\
\hline
\end{tabular}

Explanation:

** difference of high significance $(P \leq 0.01)$

$\mathrm{R}$ - correlation coefficient, $\mathrm{N}$ - number of animals, cTSH - canine thyroid stimulating hormone,

cT4 - canine tetraiodothyronine, T4 - tetraiodothyronine

or liver disorders may

the blood cell were present in the studied animals. The clinical symptoms are preliminary indicators leading to the diagnosis of hypothyreosis in dogs. Some of them, such as chills without hypothermia, have a strong connection with hypothyreosis. Other disorders like obesity, Horner's syndrome, facial paralysis, megaesophagus, laryngeal paralysis, or dilated cardiomyopathy and diarrhoea are not specific. Kidney lead to a reduction of T4 concentration (Gosselin et al. 1980; Peterson and Ferguson 1989). Kidney diseases may cause an increased loss of protein that binds the thyroid hormones. Liver conditions may also disturb the production of binding proteins, especially TBPA (thyroxine-binding prealbumin) (Larsson and Pettersson 1987). The level of binding proteins can also be lower in the course of protein-losing enteropathy and severe parasitic

Table 5. Mean cTSH concentration in blood serum in control and experimental groups shown by dog breed.

\begin{tabular}{llccccccc}
\hline Parameter & Breed & $\begin{array}{c}\text { P between } \\
\text { groups }\end{array}$ & $\mathrm{N}$ & $\begin{array}{c}\text { Control group } \\
\text { Mean }\end{array}$ & $\mathrm{SE}$ & $\mathrm{N}$ & $\begin{array}{c}\text { Experimental group } \\
\text { Mean }\end{array}$ & SE \\
\hline cTSH (ng/ml) & Dachshund & 0.573 & 3 & 0.13 & 0.02 & 4 & 0.19 & 0.05 \\
& Retriever & 0.217 & 6 & 0.11 & 0.02 & 6 & 0.15 & 0.02 \\
& Other & 0.717 & 26 & 0.18 & 0.02 & 8 & 0.29 & 0.07 \\
& Total & 0.396 & 35 & 0.16 & 0.01 & 18 & 0.21 & 0.03 \\
\multicolumn{1}{l}{ P between breeds within the group } & & & 0.093 & & & 0.802 & \\
\hline
\end{tabular}

cTSH - canine thyroid stimulating hormone, $\mathrm{N}$ - number of animals

Table 6. Mean cT4 and T4 levels in serum divided by dog breeds.

\begin{tabular}{|c|c|c|c|c|c|c|c|c|}
\hline \multirow{2}{*}{ Parameter } & \multirow{2}{*}{ Breed } & \multirow{2}{*}{$P$} & \multicolumn{3}{|c|}{ Control group } & \multicolumn{3}{|c|}{ Experimental group } \\
\hline & & & $\mathrm{N}$ & Mean & $\mathrm{SE}$ & $\mathrm{N}$ & Mean & SE \\
\hline \multirow[t]{4}{*}{$\mathrm{cT} 4(\mu \mathrm{g} / \mathrm{dl})$} & Dachshund & $0.000 * *$ & 3 & 2.25 & 0.22 & 4 & 0.85 & 0.08 \\
\hline & Retriever & $0.000 * *$ & 6 & 2.51 & 0.19 & 6 & 1.03 & 0.06 \\
\hline & Other & $0.000 * *$ & 26 & 2.26 & 0.09 & 8 & 0.91 & 0.07 \\
\hline & Total & $0.000 * *$ & 35 & 2.33 & 0.07 & 18 & 0.94 & 0.04 \\
\hline \multicolumn{3}{|c|}{$P$ between breeds in group } & & 0.239 & & & 0.245 & \\
\hline \multirow[t]{4}{*}{$\mathrm{T} 4(\mu \mathrm{g} / \mathrm{dl})$} & Dachshund & $0.043 *$ & 3 & 2.06 & 0.43 & 4 & 1.04 & 0.14 \\
\hline & Retriever & $0.000 * *$ & 6 & 2.68 & 0.22 & 6 & 1.23 & 0.11 \\
\hline & Other & $0.000 * *$ & 26 & 2.12 & 0.13 & 8 & 0.91 & 0.10 \\
\hline & Total & $0.000 * *$ & 35 & 2.27 & 0.11 & 18 & 1.09 & 0.06 \\
\hline \multicolumn{3}{|c|}{$\mathrm{P}$ between breeds in group } & & 0.097 & & & 0.139 & \\
\hline
\end{tabular}

$\mathrm{N}$ - number of animals, cT4 - canine tetraiodothyronine, T4 - tetraiodothyronine 
infections. The link between anaemia and thyroid dysfunction was also noted in some diseases. Due to those reasons, the animals with hepatic and renal impairments were not included in the study. The next stage concerned the evaluation of the correlation between T4, TSH and the haematologic changes in the blood. A positive correlation between T4 and red blood cell indices, such as $\mathrm{MCH}, \mathrm{MCHC}$, and a negative correlation with haematocrit were observed (Table 3). The patients with hypothyreosis have low erythropoietin concentration in blood plasma (Das et al. 1975). The observed changes are considered a physiological adaptation to the lower oxygen demand in the tissues caused by the reduced basic metabolism in the course of hypothyreosis. Such results point to the important effect of thyroxine on erythropoiesis. The results are confirmed by the literature data describing the influence of thyroid hormones on the production of erythropoietin. This defines another limitation of this study - lack of information on the erythropoietin levels in dogs in the study groups. The broadly described normocytic normochromic non-regenerative anaemia was not observed in the dogs with hypothyreosis in this research (Campora et al. 2011). This can be explained by the fact that the dogs with hypothyreosis in this study may have been diagnosed in the early stages of the disease, where the changes in the red blood cell system concerned only the red blood cell indices and the anaemia manifesting itself clinically and in the laboratory was a consecutive symptom if the treatment was not undertaken. This observation is partially consistent with other studies, which noted the casual link between the changes in red blood cell system and the function of thyroid in dogs and humans.

\section{Conflict of interest}

The author certifies that she has no affiliation with or financial involvement in any organization or entity with a direct financial interest in the subject matter or the materials discussed in the manuscript.

\section{References}

Campora C, Freeman KP, Lewis FI, Gibson G, Sacchini F, Sanchez-Vazquez MJ 2011: Determination of hematological reference intervals in healthy adult greyhounds. J Small Anim Pract 52: 301-309

Das KC, Mukherjee M, Sarkar TK, Dash RJ, Rastogi GK 1975: Erythropoiesis and erythropoietin in hypo- and hyperthyroidism. J Clin Endocrinol Metab 40: 211-220

den Elzen WP, de Craen AJ, Mooijaart SP, Gussekloo J 2015: Low thyroid function and anemia in old age: the Leiden 85-plus study. J Am Geriatr Soc 63: 407-409

Dorgalaleh A, Mahmoodi M, Varmaghani B, Kiani Node F, Saeeidi Kia O 2013: Effect of thyroid dysfunctions on blood cell count and red blood cell indice. Iran J Ped Hematol Oncol 3: 73-77

Fandrey J, Pagel H, Frede S, Wolff M, Jelkmann W 1994: Thyroid hormones enhance hypoxia-induced erythropoietin production in vitro. Exp Hematol 22: 272-277

Gianoukakis AG, Leigh MJ, Richards P, Christenson PD, Hakimian A 2009: Characterization of the anaemia associated with Graves' disease. Clin Endocrinol 70: 781-787

Golde DW, Bersch N, Chopra IJ, Cline MJ 1977: Thyroid hormones stimulate erythropoiesis in vitro. Br J Haematol 37: 173-177

Gosselin SJ, Capen CC, Martin SL 1980: Biochemical and immunogical investigations on hypothyroidism in dogs. Can J of Comp Med 44: 158-168

Guyton AC, Hall JE 2006: Textbook of Medical Physiology. 11 ${ }^{\text {th }}$ edn. Philadelphia, Elsevier Saunders, pp. 419-438

Kaneko JJ, Harvey JW, Bruss ML 2008: Appendix IX: blood analyte reference values in small and some laboratory animals. In: Kaneko JJ, Harvey JW, Bruss ML (eds): Clinical Biochemistry of Domestic Animals. $6^{\text {th }}$ edn. San Diego, pp. 889-895

Khatiwada S, Gelal B, Baral N, Lamsal M 2016: Association between iron status and thyroid function in Nepalese children. Thyroid Res 9: 2

Larsson M, Pettersson T1987: Purification and partial characterization of thyroid hormone binding proteins in canine serum. Domest Anim Endocrinol 4: 215-229

Maede Y, Inaba M, Taniguchi N 1983: Increase of Na-K-ATPase activity, glutamate, and aspartate uptake in dog erythrocytes associated with hereditary high accumulation of GSH, glutamate, glutamine, and aspartate. Blood 61: 493-499

Malgor LA, Blanc CC, Klainer E, Irizar SE, Torales PR 1975: Direct effects of thyroid hormones on bone marrow erythroid cells of rats. Blood 45: 671-679 
Malgor LA, Valsecia ME, Verges EG, de Markowsky EE 1995: Enhancement of erythroid colony growth by triiodothyronine in cell cultures from bone marrow of normal and anemic rats with chronic renal failure. Acta Physiol Pharmacol Ther Latinoam 45: 79-86

Omar S, Hadj Taeib S, Kanoun F, Hammami MB, Kamoun S 2010: Erythrocyte abnormalities in thyroid dysfunction. Tunis Med 88: 783-788

Peterson ME, Ferguson DC 1989: Thyroid diseases. In: Ettinger SJ (Ed.): Textbook of Veterinary Internal Medicine. Philadelphia, WB Saunders, pp. 1632-1675

Porter JA Jr, Canaday WR Jr. 1971: Hematologic values in mongrel and greyhound dogs being screened for research use. J Am Vet Ned Assoc 159: 1603-1606

Refaat B 2015: Prevalence and characteristics of anemia associated with thyroid disorders in non-pregnant Saudi women during the childbearing age: A cross-sectional study. Biomed J 38: 307-316

Rijnberg A, Kooistra HS (2010) Clinical Endocrinology of Dogs and Cats, an Illustrated Text. $2^{\text {nd }}$ edn. Schlütersche Verlagsgesellschaft, Hannover, pp. 55-91

Sullivan PS, Evans HL, McDonalds TP 1994: Platelet concentration and hemoglobin function in greyhounds. J Am Vet Med Assoc 205: 838-841

Szczepanek-Parulska E, Hernik A, Ruchala M 2017: Anemia in thyroid diseases. Pol Arch Intern Med 127: 352-360

Taylor S, Rampton D 2015: Treatment of iron deficiency anemia: practical considerations. Pol Arch Med Wewn 125: $452-460$

Torres AR, Cassle SE, Haymore M, Hill RC 2014: Hematologic differences between Dachshunds and mixed breed dogs. Vet Clin Path 43: 519-524

Vitale G, Fatti LM, Prolo S, Girola A, Caraglia M 2010: Screening for hypothyroidism in older hospitalized patients with anemia: a new insight into an old disease. J Am Geriatr Soc 58: 1825-1827

Wilson GR, Curry RW, Jr 2005: Subclinical thyroid disease. Am Fam Physician 72: 1517-1524

Zaldivar-Lopez S, Marin LM, Lazbik MC, Westendorf-Stingle N, Hensley S, Couto CG 2011: Clinical pathology of Greyhounds and other sighthounds. Vet Clin Pathol 40: 414-425

Ziglioli V, Panciera DL, Troy GC, Monroe WE, Boes KM, Refsal KR 2017: Effects of levothyroxine administration and withdrawal on the hypothalamic-pituitary-thyroid axis in euthyroid dogs. J Vet Intern Med 31: 705-710 